\title{
Foreign Direct Investment in the Function of Economic Development - Example of Selected Countries in the Western Balkans
}

\author{
Ivana Slavoljub Domazet ${ }^{1, a^{*}}$ and Darko Milivoj Marjanovic ${ }^{2, b}$ \\ ${ }^{1}$ Business Economy, Institute of Economic Sciences, Belgrade, Serbia \\ ${ }^{2}$ Finance, BB TRADE, Zrenjanin, Serbia \\ aivana.domazet@ien.bg.ac.rs, ${ }^{b}$ marjanovic79@yahoo.com
}

\begin{abstract}
Keywords: Foreign Direct Investment, Economic Development, Exports, Imports, GDP.
\end{abstract}
\begin{abstract}
The main aim of this work is to determine, on the basis of empirical research, whether and to what extent foreign direct investment has impact on the overall economic development of selected countries in the Western Balkans. Analyses made for the purpose of this paper were performed on the basis of available secondary data possessed by the World Bank for the period of 2000-2012. The research methodology involved the use of the techniques of linear regression and correlation analysis. The first task was to determine whether there is an impact of foreign direct investment on the overall economic development of these countries. Where such influence occurred, it was necessary to define its level in comparison to the influence of other variables. The results of the analysis in this paper suggest that inflow of foreign direct investment does not affect to a significant extent the economic development of selected countries in the Western Balkans.
\end{abstract}

\section{Introduction}

When foreign direct investment is concerned and its investment in a particular country, it is referred primarily to multinational companies which possess capital, technology and knowledge and countries which do not have their own resources to finance development, but have the aim to attract foreign investment. In a situation when the domestic market has become too narrow for placement of goods and services, multinational companies are trying to expand to new markets [1], [2]. In order to create a favorable investment climate for foreign investment it is very important to offer various tax benefits to multinational companies in the form of low tax rates, tax incentives and tax exemptions [3]. Multinational companies invest their private capital so their motives are of economic nature [4]. The basic motive of any multinational company to invest capital in the foreign country is, above all, profit, new market, favorable conditions for utilization of resources as well as the benefits of the tax system [5]. One of the important issues when making a decision about investing capital is the cheap labor that is usually offered in the selected country. From all stipulated above, it can be seen that multinational companies have various motives to invest their capital, but still the biggest motive is profit that the company would gain in a certain period of time [6].

Nowadays, state borders are generally not an obstacle to the movement of goods and capital. Therefore, one of the main targets of foreign investors is to increase their profits through capital investment in certain, mainly transition countries and developing countries [7]. For these countries, the entry of foreign capital is of great importance, since it will thus lead to an increase in production, improvement of technological processes, rise in efficiency of domestic enterprises, promotion of foreign trade but also increase in revenues. In this situation, the task of a foreign investor is to choose a country that would offer the best conditions for investment at a given time. From that it can be concluded that countries would be competing to attract investors and their capital, which automatically creates competition that is beneficial to the investor [8], [9].

The subject of research conducted in this paper is to determine the impact of foreign direct investment, exports and imports on the development of a number of countries of the Western Balkans, which is manifested through changes in gross domestic product. Based on theoretical knowledge which follows the topical problem, the aim of research has been determined, which was supposed to provide the answer to the question of whether and to what extent foreign direct 
investment has an impact on the economic development of Bosnia and Herzegovina, Macedonia and Montenegro. As considered by the makers of fiscal policy, foreign direct investment is highly ranked in terms of its importance to the development of the national economies [10], [11]. This view is shared by both professional public and many authors dealing with this issue. However, the starting points gave a somewhat different picture of the importance of foreign direct investment, thus making this research even more significant. Given the results that have been obtained in this analysis, it can be stated that this is an area which has not been given enough attention from the standpoint of scientific research; therefore, the results presented in this paper are very significant. Using the appropriate statistical methods, a certain step forward has been made in terms of understanding foreign direct investment and its impact on economic development of the countries that were analyzed, pointing out the scientific contribution of this research.

\section{Theory}

Foreign direct investment involves investment of capital by foreign companies or individuals, all with the aim of performing profitable activities in the territory of a state. Foreign direct investment refers to investment of capital by investors, residents of one country in the company of another country, establishing a long-term cooperation for mutual benefits [12], [13], [14]. In such situation, the foreign investor has full control or a decisive influence on the management of the company in which he invested capital. Exercising control is important because of the possibility of decisive influence on the company's operations and reducing risk [15], [16]. In the conditions of globalization, when state borders have not been obstacles to the movement of goods and capital, foreign investors are increasingly investing their capital abroad to ensure economic benefits and higher profits [17].

Wang et al. believe that the main condition for that is, above all, economic and political stability of the countries in which the capital is invested, with the existence of an economic system that will allow an adequate transfer of profits [18]. Speaking of forms, these authors observe foreign direct investment primarily in the way it enters a particular country: as a greenfield investment, $\mathrm{M} \& \mathrm{~A}$ and joint venture. Foreign direct investment can bring many benefits to the country, in which it is invested, through the transfer of knowledge and technology to domestic enterprises and labor, increased export opportunities, productivity and competitiveness [19].

The main benefits that foreign direct investment provides to recipient countries include increased production, improved technology and increased efficiency of domestic enterprises, human capital development, the promotion of foreign trade, increased revenues and greater benefits for domestic investors [5].

Doing business beyond their borders multinational companies are faced with significant influence of various political risks, which represent the probability that such an effect would lead to changes in the business environment, which usually affects profit or other goals of multinational companies [20], [21].

The main objective the countries strive to achieve is a stable and long-term economic growth, which will be based on increasing investments, improving the technological basis of these countries and increasing the competitiveness of their products in the international market. In achieving this objective, foreign direct investment can play a significant role. One group of authors found it can directly contribute to the transition process through the inflow of capital, but also indirectly through technology transfer, managerial, production and organizational 'know-how', creating new sales channels for domestic enterprises as well as through increased competition and restructuring of the domestic economy [22], [23]. This contribution is empirically documented by researches [24] who show that foreign direct investment and trade in particular contribute toward advancing economic growth in developing countries in a strong, positive interaction, and stimulate domestic investment. Others [25] indicate that in developing European countries there is bidirectional causality between gross domestic product and foreign direct investment and unidirectional causality to trade in shortrun. In addition, some researchers [26] exploring relationship between economic grow, gross domestic product, foreign direct investment, and trade found two-way causal connections existence 
between economic growth, foreign direct investment and exports, with rather weaker evidence of feedback from imports to the other three. But, there was no consensus of foreign direct investment impact on economic grow because there some empirical research fall to find evidence about it. For example some authors found that domestic investment is crucial, it represents important determinant of growth of national economy and foreign direct investment did not have any significant impact on growth [27].

Ćoric and Pugh showed two models that relate to investment in the countries of Western Balkans [28]. The first model refers to the establishment of new companies that are owned by a foreign entity (greenfield investments). This model of the entry of foreign direct investment is not very common, mostly because of the great risks that exist in some countries, but also unstable economic conditions. The second model refers to the investment of foreign capital in the purchase of domestic companies (privatization). This form of privatization can be seen through the direct purchase of companies (purchase of a part or in whole of state-owned companies) or indirect purchases (a joint venture by the foreign investors and domestic enterprise, which is state-owned). If countries of the Western Balkans are taken into consideration, it can be stated that there were very few greenfield investments, as well as investments in export-oriented projects and production [5], [29].

The prerequisite for economic growth in each country is the financial development. The financial sector is very important due to the fact it has a significant role in mobilizing financial resources for investing, as well as for encouraging the entry of foreign investors into new markets. Investment opportunities, their tracking, and facilitating the exchange of goods and services will reduce transaction costs, which inevitably lead to economic growth [30], [31]. The requirement to attract foreign direct investment is becoming one of the key prerequisites for future economic growth, especially for the countries of South East Europe, which aim to become EU members [32], [33] and consequently we can say that FDI are considered as the driver of economic growth [34].

For most countries of the Western Balkans, there were significantly higher inflows of foreign investments in the period of 2006-2010, mostly under the influence of a different development strategy that was more oriented towards the real development needs of the region [35], [36]. In the following years, it is expected that Central and Eastern European countries continue to stimulate the entry of FDI mostly through liberal trade policies, with the tendency of an increase in exports, which is highly important for multinationals [37].

In contrast to the gradual approach of transition, several countries have opted for the expedient liberalization of prices and privatization of state firms, with the expectation that this will lead to rapid transition to a healthy market-oriented economy in which entrepreneurs usher in capitalism. Where privatization and downsizing of state-owned enterprises cause mass unemployment, there is often a mismatch between market demand and skills available in the workforce [38].

Foreign direct investment is the biggest development opportunity of economies from the Western Balkans and the best way to increase production, employment, exports and living standards in the longer term [39], [40]. Foreign direct investment is considered to be an effective way of raising the comparative advantages of a country, and as such most relate to developing countries that need internationalization of operations, in which the main actors are precisely multinationals [41], [42]. The basic motives of each multinational company for investing capital in a foreign country, among other things, are profits, a new market, favorable conditions for the use of resources, and the benefits of the tax system [43], [44].

Tax reforms are necessary in all economies of the Western Balkans, considering that it is essential to adjust the tax system and harmonize it with solutions from the most developed countries [45], [46]. These reforms are partly the result of internal changes, but they also, on the other hand, were significantly influenced by the process of globalization and the increase in international capital mobility [47]. If the state has a budget deficit, the growth of public expenditures, the deficit in the balance of payments, and the lack of a general tax culture, it is not possible to establish a viable tax system [48], [49]. 


\section{Research Methodology}

The starting point in this research was the available secondary data, disposed by the World Bank. This is very important because it will ensure data originating from a single source, because only as such, they would be mutually comparable. Therefore, the analysis will not affect the potential differences in individual national methodologies that counted some of the most important macroeconomic data in selected economies (Bosnia and Herzegovina, Macedonia and Montenegro). After collecting the data, it was necessary to transform them, using appropriate methods of econometric and statistical analysis, into information based on which the conclusions would be drawn. The main indicators analyzed in this research were foreign direct investment, gross domestic product, exports and imports, in the period 2000 - 2012. These main macroeconomics indicators were chosen because they represent health of every single national economy and due frequency of usage in other similar researches [24-27].

Relevant data for this analysis are shown in Appendix (Table A1. GDP, Export, FDI, and Import for selected countries of the Western Balkans).

Given the characteristics of secondary data that were available in the electronic database, World Development Indicator, it was necessary to process them using the techniques of linear regression and correlation analysis. The two techniques were chosen because of the characteristics of the secondary data that was available and, above all, with regards to the following:

1. normality, linearity and stationarity of available time series, i.e. predictability of their movements during the observed time period of 13 years,

2. degrees of freedom in analyzes that were allowed and acceptable, and

3. ensuring that the use of the above stipulated techniques provide more reliable results.

The task of linear regression analysis was to adequately demonstrate if there was an impact of foreign direct investment to the overall economic development of Bosnia and Herzegovina, Macedonia and Montenegro. Following the results obtained by using that method, it was necessary, applying correlation analysis, in the part where there was an impact, to define the level in comparison to the influence of other variables. For the application of these techniques Statistical Package for the Social Sciences, version 16.0 was used.

During the augmented Dickey-Fuller test of the unit root, the time series for selected countries have shown very unsteady movement. To be possible to start application of the regression analysis, i.e. to optimize the available data and transform them into stationary series, one of the solutions was to make logarithmic differentiation of data from successive time series.

In that way, it was ensured that, instead of observing the levels of time series, for instance the state of GDP or FDI, their relative growth was observed. For example, the difference of the logarithm of GDP of $0.05 \%$ indicates that GDP grew by $5 \%$, or a difference of logarithm for FDI of $0.1 \%$ shows that FDI rose by $10 \%$. In that way, in case of non-stationary data on macroeconomic indicators of the analyzed countries a significant improvement was made in terms of their stationarity.

Data analysis for Bosnia and Herzegovina, Macedonia and Montenegro was conducted using three methods of modeling linear regression: forward method, backward method and stepwise method. The main role of these methods was to adequately identify the main explanatory variables in the regression, in a situation where there were more potential independent variables that could explain the dependent variable. For this reason, the analysis needed to be gradual.

GDP as macroeconomic aggregate, functioning and being determined by several explanatory variables was observed by the formula, as follows:

$$
G D P=\mathrm{S}+E+I+(X-M),
$$

where $S=$ spending, $E=$ state expenditures, $I=$ investments, $X-M=$ net exports, i.e. difference between exports and imports.

Based on this formula, it is ensured that all explanatory variables - FDI, exports and imports determine GDP. And it is the appearance of FDI in the final model, applied to Bosnia and Herzegovina, Macedonia and Montenegro that should emphasize the significance which foreign 
direct investment has in its overall economic development. To determine the impact of foreign direct investment in the development of Bosnia and Herzegovina, Macedonia and Montenegro, Spearman rank correlation was used.

\section{Research Results}

Considering that the aim of the analysis was to identify the impact of foreign direct investment on the development of Bosnia and Herzegovina, Macedonia and Montenegro, for dependent variables that most distinctively illustrate the economic category GDP was taken and changes in GDP since it is operated with the logarithm difference data.

For potentially explanatory variables direct foreign investment, exports and imports were used, as well as generated variables of GDP1, FDI1, exports1, imports1, variables with a delay of one year, since the country's development from the previous year can affect its development in the current year.

\section{(a) Regression analysis for Bosnia and Herzegovina}

By applying the forward method results were obtained as shown in Table 1.

Table 1. Regression analysis for Bosnia and Herzegovina - forward method.

\begin{tabular}{|c|c|c|c|}
\hline \multicolumn{3}{|c|}{ Variables Entered/Removed $^{\text {a }}$} \\
\hline Model & Variables Entered & Variables Removed & Method $^{-1}$ \\
\hline 1 & ImportBIH & $\cdot$ & $\begin{array}{c}\text { Forward (Criterion: Probability-of-F-to- } \\
\text { enter }<=0.050)\end{array}$ \\
\hline 2 & ExportBIH1 & $\cdot$ & $\begin{array}{c}\text { Forward (Criterion: Probability-of-F-to- } \\
\text { enter }<=0.050)\end{array}$ \\
\hline
\end{tabular}

Source: Authors`calculations

They show that at the level of values $\mathrm{F}$ - statistics $\mathrm{F} \leq 0.050$ there is a relation between exports and GDP, and imports and GDP in the analyzed case of Bosnia and Herzegovina.

By applying the backward method, whose main indicators are presented in Table 2, a similar conclusion has been drawn at the level of values of $F$-statistics $F \leq 0.100$. As for the FDI components and FDI components with a delay of one year they are excluded from further analysis at the very beginning of the process, which points out the smallest importance of the potential relation between FDI and GDP in the case of Bosnia and Herzegovina.

Table 2. Regression analysis for Bosnia and Herzegovina - backward method.

\begin{tabular}{|c|c|c|c|}
\hline \multicolumn{4}{|c|}{ Variables Entered/Removed $^{\mathrm{b}}$} \\
\hline Model & Variables Entered & $\begin{array}{l}\text { Variables } \\
\text { Removed }\end{array}$ & Method \\
\hline 1 & $\begin{array}{l}\text { ImportBIH1, ExportBIH, FDIBIH1, } \\
\text { FDIBIH, ExportBIH1, ImportBIH, } \\
\text { gdpBIH1 }^{\mathrm{a}}\end{array}$ & $\cdot$ & Enter \\
\hline 2 & . & FDIBIH & $\begin{array}{c}\text { Backward (criterion: Probability of F-to- } \\
\text { remove }>=0.100 \text { ). }\end{array}$ \\
\hline 3 & . & FDIBIH1 & $\begin{array}{l}\text { Backward (criterion: Probability of F-to- } \\
\text { remove }>=0.100 \text { ). }\end{array}$ \\
\hline 4 & . & gdpBIH1 & $\begin{array}{c}\text { Backward (criterion: Probability of F-to- } \\
\text { remove }>=0.100 \text { ). }\end{array}$ \\
\hline 5 & . & ImportBIH1 & $\begin{array}{c}\text { Backward (criterion: Probability of F-to- } \\
\text { remove }>=0.100 \text { ). }\end{array}$ \\
\hline 6 & . & ExportBIH & $\begin{array}{c}\text { Backward (criterion: Probability of F-to- } \\
\text { remove }>=0.100 \text { ). }\end{array}$ \\
\hline \multicolumn{4}{|c|}{ a. All requested variables entered. } \\
\hline & & & \\
\hline
\end{tabular}




\begin{tabular}{|c|c|c|c|c|}
\hline \multicolumn{2}{|c|}{} & \multicolumn{3}{c|}{ Model Summary } \\
\hline Model & $\mathrm{R}$ & R Square & Adjusted R Square & Std. Error of the Estimate \\
\hline 1 & $0.940^{\mathrm{a}}$ & 0.883 & 0.610 & 0.070264 \\
\hline 2 & $0.940^{\mathrm{b}}$ & 0.883 & 0.707 & 0.060873 \\
\hline 3 & $0.939^{\mathrm{c}}$ & 0.881 & 0.762 & 0.054892 \\
\hline 4 & $0.935^{\mathrm{d}}$ & 0.874 & 0.790 & 0.051467 \\
\hline 5 & $0.934^{\mathrm{e}}$ & 0.872 & 0.817 & 0.048082 \\
\hline 6 & $0.930^{\mathrm{f}}$ & 0.865 & 0.832 & 0.046127 \\
\hline
\end{tabular}

Source: Authors`calculations

Table 3. Regression analysis for Bosnia and Herzegovina - stepwise method.

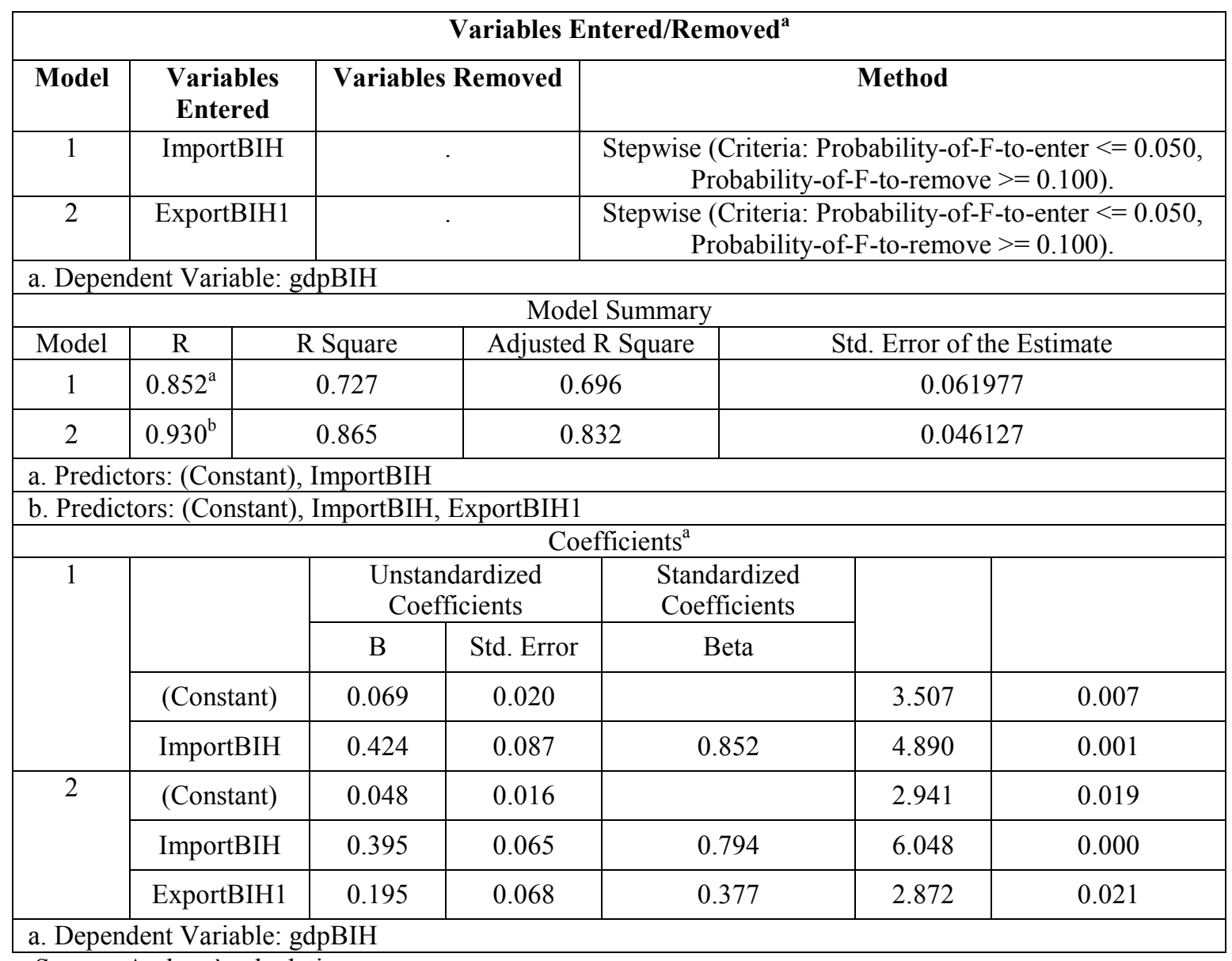

Source: Authors`calculations

Finally, the application of the stepwise method, the results of which are shown in Table 3, confirms the connection of imports with GDP in Bosnia and Herzegovina on the basis of the value of $F$-statistics $F \leq 0.100, F \leq 0.050$, and argues that the relation between these two variables, expressed by parameters of regression correlation coefficient $(R=0.852)$, regression coefficient of determination $\left(R^{2}=0.727\right)$, and the adjusted regression coefficient of determination $\left(\right.$ Adj. $\left.R^{2}=0.696\right)$ can confirm, on the basis of the strength of the $R(\min =0, \max =1)$ and the value of $R^{2}$ and $A d j . R^{2}$, which indicate that imports and GDP in Bosnia and Herzegovina share even between $69.6 \%$ and $72.7 \%$ of total variance.

However, stepwise method confirmed the relation of imports and exports with GDP in Bosnia and Herzegovina on the basis of the value of $F$ statistics $F \leq 0.100, F \leq 0.050$, and claims that this relation, expressed by parameters of regression correlation coefficient $(R=0.930)$, regression coefficient of determination $\left(R^{2}=0.865\right)$, and the adjusted regression coefficient of determination (Adj. $R^{2}=0.832$ ) can confirm, on the basis of the strength of the very $R(\min =0, \max =1)$, and the 
value of $R^{2}$ and $A d j . R^{2}$ indicating that the imports and exports in Bosnia and Herzegovina share with BDP even between $83.2 \%$ and $86.5 \%$ of total variance.

Table 4. Correlation analysis for variables in Bosnia and Herzegovina.

\begin{tabular}{|l|c|c|c|c|c|c|c|c|}
\hline rho & $\begin{array}{c}\text { gdp } \\
\text { BIH }\end{array}$ & $\begin{array}{c}\text { Export } \\
\text { BIH }\end{array}$ & $\begin{array}{c}\text { FDI } \\
\text { BIH }\end{array}$ & $\begin{array}{c}\text { Import } \\
\text { BIH }\end{array}$ & $\begin{array}{c}\text { gdp } \\
\text { BIH1 }\end{array}$ & $\begin{array}{c}\text { Export } \\
\text { BIH1 }\end{array}$ & $\begin{array}{c}\text { FDI } \\
\text { BIH1 }\end{array}$ & $\begin{array}{c}\text { Import } \\
\text { BIH1 }\end{array}$ \\
\hline gdpBIH & 1.000 & & & & & & & \\
\hline ExportBIH & $0.825^{* *}$ & 1.000 & & & & & & \\
\hline FDIBIH & 0.392 & 0.483 & 1.000 & & & & & \\
\hline ImportBIH & $0.916^{* *}$ & $0.713^{* *}$ & 0.427 & 1.000 & & & & \\
\hline gdpBIH1 & 0.345 & 0.227 & -0.464 & 0.191 & 1.000 & & & \\
\hline ExportBIH1 & 0.373 & 0.191 & -0.273 & 0.355 & $0.773^{* *}$ & 1.000 & & \\
\hline FDIBIH1 & 0.500 & 0.291 & -0.264 & 0.491 & 0.282 & 0.382 & 1.000 & \\
\hline ImportBIH1 & 0.209 & -0.073 & -0.564 & 0.082 & $0.891^{* *}$ & $0.627^{*}$ & 0.327 & 1.000 \\
\hline ** Correlation is statistically significant at the level of $\mathrm{p}<0.01$ \\
* Correlation is statistically significant at the level of $<0.05$ \\
Source: Authors' calculations
\end{tabular}

According to the regression model in Bosnia and Herzegovina changes in imports can predict changes in GDP at the level of $B=0.424, t(4.890), p=0.001$, while the changes in exports can predict changes in GDP at the level of $B=0.195, t(2.872), p=0.021$.

Results of correlation analysis with the variables available for Bosnia and Herzegovina are shown in Table 4.

The resulting correlation matrix shows the existence of several statistically significant relations based on the correlation coefficients at the levels of $p<0.01$ and $p<0.05$, as follows:

$1)$ in the column gdpBIH: $\left(r h o_{\text {ExportBIH }}=0.825\right)<\left(r h o_{\text {ImportBIH }}=0.916\right)$

$2)$ in the column gdpBIH1: $\left(\right.$ rho $\left._{\text {ExportBIHI }}=0.773\right)<\left(\right.$ rho $\left._{\text {ImportBIHI }}=0.891\right)$

That means that the connection of GDP with exports and imports in Bosnia and Herzegovina was identified at original data, i.e. that the same relations are identified on logarithmic differentiated data. According to Cohen's criteria for the size of rank correlation rho, in case of Bosnia and Herzegovina, the strongest relations were identified between imports and GDP, as well as their adjusted parameters imports 1 and GDP1. The relation between FDI and GDP has not been found in case of Bosnia and Herzegovina.

\section{(b) Regression analysis for Macedonia}

Applying the forward method results were obtained as shown in Table 5.

Table 5. Regression analysis for Macedonia - forward method.

\begin{tabular}{|c|c|c|c|}
\hline \multicolumn{3}{|c|}{ Variables Entered/Removed $^{\text {a }}$} \\
\hline Model & $\begin{array}{c}\text { Variables } \\
\text { Entered }\end{array}$ & $\begin{array}{c}\text { Variables } \\
\text { Removed }\end{array}$ & Method $^{-1}$ \\
\hline 1 & ImportMAC & $\cdot$ & Forward (Criterion: Probability-of-F-to-enter $<=0.050)$ \\
\hline \multicolumn{4}{|c|}{ a. Dependent Variable: gdpMAC } \\
\hline
\end{tabular}

Source: Authors`calculations

It shows that at the level of value $\mathrm{F}$ - statistics $\mathrm{F} \leq 0.050$ there is a relation between imports and GDP in the analyzed case for Macedonia.

Applying the backward method, whose main indicators are shown in Table 6, the similar conclusion has been drawn. The component that is longest retained in circulation is imports, and as far as FDI component and component SDI with a delay of one year are concerned, they are excluded from further analysis: the former, in the fourth and the latter in the second stage of the analysis. 
Table 6. Regression analysis for Macedonia - backward method.

\begin{tabular}{|c|c|c|c|c|}
\hline \multicolumn{5}{|c|}{ Variables Entered/Removed $^{\mathrm{b}}$} \\
\hline Model & \multicolumn{3}{|c|}{ Variables Entered } & Method \\
\hline 1 & \multicolumn{3}{|c|}{ 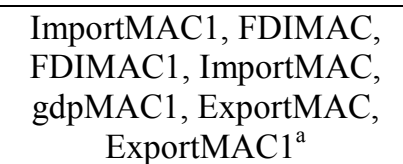 } & Enter \\
\hline 2 & \multicolumn{3}{|c|}{. } & $\begin{array}{c}\text { Backward (criterion: Probability of F- } \\
\text { to-remove }>=0.100) .\end{array}$ \\
\hline 3 & \multicolumn{3}{|c|}{. } & $\begin{array}{c}\text { Backward (criterion: Probability of F- } \\
\text { to-remove }>=0.100 \text { ). }\end{array}$ \\
\hline 4 & \multicolumn{3}{|c|}{. } & $\begin{array}{c}\text { Backward (criterion: Probability of F- } \\
\text { to-remove }>=0.100) .\end{array}$ \\
\hline 5 & \multicolumn{3}{|c|}{$\cdot$} & $\begin{array}{l}\text { Backward (criterion: Probability of F- } \\
\text { to-remove }>=0.100 \text { ). }\end{array}$ \\
\hline \multicolumn{5}{|c|}{ a. All requested variables entered. } \\
\hline \multicolumn{5}{|c|}{ b. Dependent Variable: gdpMAC } \\
\hline \multicolumn{5}{|c|}{ Model Summary } \\
\hline Model & $\mathrm{R}$ & $\begin{array}{c}\mathrm{R} \\
\text { Square }\end{array}$ & Adjusted R Square & Std. Error of the Estimate \\
\hline 1 & $0.980^{\mathrm{a}}$ & 0.960 & & 0.037789 \\
\hline 2 & $0.979^{\mathrm{b}}$ & 0.959 & & 0.032827 \\
\hline 3 & $0.975^{\mathrm{c}}$ & 0.951 & & 0.032112 \\
\hline 4 & $0.961^{\mathrm{d}}$ & 0.923 & & 0.036791 \\
\hline 5 & $0.954^{\mathrm{e}}$ & 0.910 & & 0.036841 \\
\hline \multicolumn{5}{|c|}{$\begin{array}{l}\text { a. Predictors: (Constant), ImportMAC1, FDIMAC, FDIMAC1, ImportMAC, gdpMAC1, ExportMAC, } \\
\text { ExportMAC1 }\end{array}$} \\
\hline \multicolumn{5}{|c|}{ b. Predictors: (Constant), ImportMAC1, FDIMAC, ImportMAC, gdpMAC1, ExportMAC, ExportMAC1 } \\
\hline \multicolumn{5}{|c|}{ c. Predictors: (Constant), ImportMAC1, FDIMAC, ImportMAC, ExportMAC, ExportMAC1 } \\
\hline \multicolumn{5}{|c|}{ d. Predictors: (Constant), ImportMAC1, ImportMAC, ExportMAC, ExportMAC1 } \\
\hline \multicolumn{5}{|c|}{ e. Predictors: (Constant), ImportMAC1, ImportMAC, } \\
\hline
\end{tabular}

Finally, the application of the stepwise method, the results of which are shown in Table 7, confirms the relation of imports with GDP in Macedonia on the basis of the value of $F$ statistics $\mathrm{F} \leq 0.100, \mathrm{~F} \leq 0.050$, and argues that the relationship of these two variables expressed by parameters of regression correlation coefficient $(R=0.844)$, regression coefficient of determination $\left(R^{2}=0.712\right)$, and the adjusted regression coefficient of determination $\left(A d j \cdot R^{2}=0.680\right)$ can be confirmed on the basis of the strength of $R(\min =0, \max =1)$, and the value of $R^{2}$ and $A d j . R^{2}$ which indicate that imports and GDP in Macedonia share between $68 \%$ and $71.2 \%$ of total variance.

Table 7. Regression analysis for Macedonia - stepwise method.

\begin{tabular}{|c|c|c|c|c|c|}
\hline \multicolumn{6}{|c|}{ Variables Entered/Removed ${ }^{\mathfrak{c}}$} \\
\hline Model & \multicolumn{2}{|c|}{$\begin{array}{l}\text { Variables } \\
\text { Entered }\end{array}$} & \multicolumn{2}{|r|}{ Variables Removed } & Method \\
\hline 1 & \multicolumn{2}{|c|}{ ImportMAC } & & . & $\begin{array}{c}\text { Stepwise (Criteria: Probability-of-F-to-enter }<= \\
0.050, \text { Probability-of-F-to-remove }>=0.100)\end{array}$ \\
\hline \multicolumn{6}{|c|}{ a. Dependent Variable: gdpMAC } \\
\hline \multicolumn{6}{|c|}{ Model Summary } \\
\hline Model & $\mathrm{R}$ & \multicolumn{2}{|c|}{$\begin{array}{c}\text { R } \\
\text { Square }\end{array}$} & $\begin{array}{l}\text { Adjusted R } \\
\text { Square }\end{array}$ & Std. Error of the Estimate \\
\hline 1 & $0.844^{\mathrm{a}}$ & \multicolumn{2}{|c|}{0.712} & 0.680 & 0.058177 \\
\hline
\end{tabular}




\begin{tabular}{|c|c|c|c|c|c|c|}
\hline \multicolumn{7}{|c|}{ Coefficients $^{\mathrm{a}}$} \\
\hline \multirow[t]{4}{*}{1} & & \multicolumn{2}{|c|}{$\begin{array}{l}\text { Unstandardized } \\
\text { Coefficients }\end{array}$} & Standardized Coefficients & & \\
\hline & & $\mathrm{B}$ & Std. Error & Beta & & \\
\hline & (Constant) & 0.031 & 0.022 & & 1.406 & 0.193 \\
\hline & ImportMAC & 0.519 & 0.110 & 0.844 & 4.719 & 0.001 \\
\hline
\end{tabular}

a. Dependent Variable: gdpMAC

Source: Authors' calculations

According to regression model in Macedonia, changes in imports can predict changes in GDP at the level of $B=0.519, t(4.719), p=0.001$.

Results of correlation analysis with the variables available for Macedonia are shown in Table 8.

Table 8. Correlation analysis for variables in Macedonia.

\begin{tabular}{|l|c|c|c|c|c|c|c|c|}
\hline$r h o$ & $\begin{array}{c}\text { gdp } \\
\text { MAC }\end{array}$ & $\begin{array}{c}\text { Export } \\
\text { MAC }\end{array}$ & $\begin{array}{c}\text { FDI } \\
\text { MAC }\end{array}$ & $\begin{array}{c}\text { Import } \\
\text { MAC }\end{array}$ & $\begin{array}{c}\text { gdp } \\
\text { MAC1 }\end{array}$ & $\begin{array}{c}\text { Export } \\
\text { MAC1 }\end{array}$ & $\begin{array}{c}\text { FDI } \\
\text { MAC1 }\end{array}$ & $\begin{array}{c}\text { Import } \\
\text { MAC1 }\end{array}$ \\
\hline gdpMAC & 1.000 & & & & & & & \\
\hline ExportMAC & $0.776^{* *}$ & 1.000 & & & & & & \\
\hline FDIMAC & 0.259 & 0.343 & 1.000 & & & & & \\
\hline ImportMAC & $0.902^{* *}$ & $0.790^{* *}$ & 0.371 & 1.000 & & & & \\
\hline gdpMNE1 & 0.273 & -0.091 & -0.255 & 0.291 & 1.000 & & & \\
\hline ExportMAC1 & -0.073 & -0.155 & 0.100 & 0.182 & 0.482 & 1.000 & & \\
\hline FDIMAC1 & 0.082 & 0.118 & -0.282 & 0.291 & 0.409 & 0.282 & 1.000 & \\
\hline ImportMAC1 & -0.055 & -0.245 & -0.282 & 0.009 & $0.791^{* *}$ & $0.727^{*}$ & 0.309 & 1.000 \\
\hline
\end{tabular}

** Correlation is statistically significant at the level of $\mathrm{p}<0.01$

* Correlation is statistically significant at the level of $p<0.05$

Source: Authors`calculations

The resulting correlation matrix shows the existence of several statistically significant relations based on the correlation coefficients at the levels of $p<0.01$ and $p<0.05$, as follows:

$1)$ in the column gdpMAC: $($ rho ExportMAC $=0.776)<\left(\right.$ rho $\left._{\text {ImportMAC }}=0.902\right)$

$2)$ in the column gdpMAC1: (rho ImportMAC1 $=0.791)$

That means that the connection of GDP with exports and imports in Macedonia was identified at original data, i.e. that the relation between GDP1 and imports1 was identified on logarithmic differentiated data. According to Cohen's criteria for the size of rank correlation rho, in case of Macedonia, the strongest relations were identified between imports and GDP, as well as their adjusted parameters imports1 and GDP1, while there is no relation between FDI and GDP.

\section{(c) Regression analysis for Montenegro}

In case of Montenegro data on FDI are only available since 2007, which makes it impossible to apply regression analysis for this country, since a time series of only six hundred members is available, which is non-linear and non-homogeneous, and which should be combined with time data for other three variables, GDP, exports and imports.

Since it is not possible to make regression analysis for Montenegro, it was only possible to estimate the impact of FDI, exports and imports on GDP of the country by application of correlation analysis. Spearman's rank correlation coefficients in the case of Montenegro are shown in Table 9. 
Table 9. Spearman correlation for variables in Montenegro.

\begin{tabular}{|l|c|c|c|c|c|c|c|c|}
\hline rho & $\begin{array}{c}\text { gdp } \\
\text { MNE }\end{array}$ & $\begin{array}{c}\text { Export } \\
\text { MNE }\end{array}$ & $\begin{array}{c}\text { FDI } \\
\text { MNE }\end{array}$ & $\begin{array}{c}\text { Import } \\
\text { MNE }\end{array}$ & $\begin{array}{c}\text { gdp } \\
\text { MNE1 }\end{array}$ & $\begin{array}{c}\text { Export } \\
\text { MNE1 }\end{array}$ & $\begin{array}{c}\text { FDI } \\
\text { MNE1 }\end{array}$ & $\begin{array}{c}\text { Import } \\
\text { MNE1 }\end{array}$ \\
\hline gdpMNE & 1.000 & & & & & & & \\
\hline ExportMNE & 0.545 & 1.000 & & & & & & \\
\hline FDIMNE & -0.500 & -0.700 & 1.000 & & & & & \\
\hline ImportMNE & $0.706^{*}$ & $0.832^{* *}$ & -0.600 & 1.000 & & & & \\
\hline gdpMNE1 & 0.309 & -0.027 & 0.700 & 0.336 & 1.000 & & & \\
\hline ExportMNE1 & -0.009 & -0.064 & 0.700 & 0.291 & 0.418 & 1.000 & & \\
\hline FDIMNE1 & -0.200 & -0.400 & -0.200 & -0.400 & -0.200 & -0.400 & 1.000 & \\
\hline ImportMNE1 & 0.209 & -0.191 & 0.700 & 0.236 & $0.627^{*}$ & $0.782^{* *}$ & -0.200 & 1.000 \\
\hline
\end{tabular}

$* *$ Correlation is statistically significant at the level of $\mathrm{p}<0.01$

* Correlation is statistically significant at the level of $\mathrm{p}<0.05$

Source: Authors`calculations

The resulting correlation matrix shows the existence of only a few statistically significant relations based on the correlation coefficients at the levels of $p<0.01$ and $p<0.05$, as follows:

1) in the column gdpMNE: $\left(\right.$ rho $\left._{\text {ImportMNE }}=0.706\right)$

2 ) in the column gdpMNE1: (rho ImportMNE1 $=0.627$ ).

That means that both the original data and the log- differentiated data for Montenegro show connection of GDP with imports only.

Table 10. Kendall's tau correlation for variables in Montenegro.

\begin{tabular}{|c|c|c|c|c|c|c|c|c|}
\hline$\tau$ & $\begin{array}{c}\text { gdp } \\
\text { MNE }\end{array}$ & $\begin{array}{l}\text { Export } \\
\text { MNE }\end{array}$ & $\begin{array}{c}\text { FDI } \\
\text { MNE }\end{array}$ & $\begin{array}{l}\text { Import } \\
\text { MNE }\end{array}$ & $\begin{array}{c}\text { gdp } \\
\text { MNE1 }\end{array}$ & $\begin{array}{l}\text { Export } \\
\text { MNE1 }\end{array}$ & $\begin{array}{c}\text { FDI } \\
\text { MNE1 }\end{array}$ & $\begin{array}{l}\text { Import } \\
\text { MNE1 }\end{array}$ \\
\hline gdpMNE & 1.000 & & & & & & & \\
\hline ExportMNE & 0.424 & 1.000 & & & & & & \\
\hline FDIMNE & -0.200 & -0.600 & 1.000 & & & & & \\
\hline ImportMNE & $0.545^{*}$ & $0.697^{* *}$ & -0.400 & 1.000 & & & & \\
\hline gdpMNE1 & 0.236 & -0.055 & 0.600 & 0.273 & 1.000 & & & \\
\hline ExportMNE1 & 0.018 & -0.055 & 0.600 & 0.200 & 0.345 & 1.000 & & \\
\hline FDIMNE1 & 0.000 & -0.333 & 0.000 & -0.333 & 0.000 & -0.333 & 1.000 & \\
\hline ImportMNE1 & 0.164 & -0.127 & 0.600 & 0.127 & $0.491^{*}$ & $0.636^{* *}$ & 0.000 & 1.000 \\
\hline
\end{tabular}

** Correlation is statistically significant at the level $\mathrm{p}<0.01$

* Correlation is statistically significant at the level $\mathrm{p}<0.05$

Source: Authors`calculations

In order to check the resulting conclusion based on the Spearman rank correlation, and given the impossibility of regression analysis, another type of nonparametric correlation analysis was carried out, i.e. Kendall's tau correlation analysis $(\tau)$. Its results are shown in Table 10.

The resulting correlation matrix also shows the existence of only a few statistically significant relations based on the correlation coefficients at the levels of $p<0.01$ and $p<0.05$, as follows:

$1)$ in the column gdpMNE: $\left(\tau_{\text {ImportMNE }}=0.545\right)$

$2)$ in the column gdpMNE1: $\left(\tau_{\text {ImportMNEI }}=0.491\right)$.

On the basis of all stipulated above, it can be concluded that in case of Montenegro the results that were obtained using Kendall's correlation confirms the results of Spearman's rank correlation. 


\section{Discussion}

Regression analysis in case of Bosnia and Herzegovina showed the existence of the relationship of imports and exports with the development of the country, while FDI, according to the obtained findings did not significantly affect the development of Bosnia and Herzegovina. This conclusion indicates that according to the results of regression, whose regression correlation coefficient is $R=0.852$, regression coefficient of determination $R^{2}=0.727$ and adjusted regression coefficient of determination equals $A d j . R^{2}=0.696$, imports and GDP in Bosnia and Herzegovina share between $69.6 \%$ and $72.7 \%$ of total variance.

In addition, imports and exports observed together in relation to GDP share between $83.2 \%$ and $86.5 \%$ of the total variance, since the corresponding regression correlation coefficient is $R=0.930$, regression coefficient of determination $R^{2}=0.865$ and adjusted regression coefficient of determination equals $A d j . R^{2}=0.832$. Thus, according to the regression model in Bosnia and Herzegovina changes in imports can predict changes in GDP at the level of $B=0.424, t(4.890)$, $p=0.001$, while the changes in exports can predict changes in GDP at the level of $B=0.195$, $t(2.872), p=0.021$.

Correlation analysis in case of Bosnia and Herzegovina confirmed the regression findings. Based on statistically significant correlations for imports $r h o=0.916$ and logarithmic differentiated imports of $r h o=0.891$ showed that this indicator has the strongest influence on the development of Bosnia and Herzegovina. Second-ranked indicator according to its impact on the development of Bosnia and Herzegovina, whose statistically significant correlation coefficients amounted to $r h o=0.825$, and $r h o=0.773$ were exports and its logarithmic adjusted parallel. The analysis did not prove the existence of the impact of FDI on development of Bosnia and Herzegovina.

The result of the regression analysis for Macedonia showed a relationship only between imports and GDP. Obtained regression correlation coefficient $R=0.844$, regression coefficient of determination $R^{2}=0.712$ and adjusted regression coefficient of determination $A d j . R^{2}=0.680$ speak in favor of that. They suggest that imports and GDP in Macedonia share between $68 \%$ and $71.2 \%$ of the total variance and that in Macedonia changes in imports can predict changes in GDP at the level of $B=0.519, t$ (4.719), $p=0.001$.

The obtained correlation matrix in the analysis for Macedonia confirmed the finding obtained by regression analysis with statistically significant coefficients of correlation of imports and GDP, i.e. their logarithmic differences of $r h o=0.902$ and $r h o=0.791$. As a novelty, the correlation discovered relation between exports and GDP in Macedonia, with a correlation coefficient of $r h o=0.776$. That means that imports was the primary factor for the development of Macedonia and that FDI have not turned to be a significant factor in the development of this country.

In case of Montenegro, and due to inability to conduct regression analysis, the conclusion is based on the results of Spearman correlation and Kendall's tau correlation. However, Spearman and Kendall's tau correlation showed the absence of the impact of FDI in GDP of Montenegro, i.e. its development. Only relations between imports and logarithmically transformed imports and GDP were determined, with statistically significant coefficients $r h o=0.545$ and $r h o=0.491$, i.e. $\tau=0.545$ and $\tau=0.491$.

\section{Conclusions}

Regression analysis conducted on the example of selected countries in the Western Balkans identified different relations of foreign direct investment, exports and imports to GDP of these countries, as well as the different composition of their GDPs. In addition to conclusions that are based on regression analysis, correlation analysis, too, revealed different strengths of relationships of the given macroeconomic indicators for the countries analyzed. However, according to the conducted analysis, it was found that there was no significant impact of FDI on economic development of Bosnia and Herzegovina, Macedonia and Montenegro.

This attitude does not exclude a certain significance of foreign direct investment, but they are certainly not the deciding factor in the development of these countries. If the period of some twenty 
years is analyzed, quite poor economic results can be noted for almost all the economies of the Western Balkans. It is, therefore, essential that foreign direct investment is treated as one of the factors that, among other factors and under certain conditions, by their synergy may improve the economic development of these countries.

In addition to the conclusions that have been reached in this research, in terms of the impact that foreign direct investment has on economic development, the countries of the Western Balkans should strive to attract more foreign direct investment in the hope that it will help create a safer and more favorable economic situation in these countries. However, in order to be competitive in the market, and thus attract a considerable amount of investments, it is inevitable to carry out the necessary reforms, reduce corruption, improve administration efficiency and create effective strategies for attracting foreign direct investment, i.e. create an attractive business environment for investments. It is also important to maintain a stable economic and financial system, as well as a competitive tax system. Along with that, it is necessary to determine the competitive advantages of these countries in relation to neighboring countries, which will have positive impact on foreign investors in the future.

\section{Conflicts of Interest}

The authors declare no conflict of interest.

\section{Acknowledgments}

This paper is a part of research project financed by the Ministry of Education, Science and Technological Development of the Republic of Serbia.

\section{Appendix}

Table A1. GDP, Export, FDI, and Import for selected countries of the Western Balkans.

\begin{tabular}{|c|c|c|c|c|c|c|c|c|c|c|c|c|c|}
\hline Country & 2000 & 2001 & 2002 & 2003 & 2004 & 2005 & 2006 & 2007 & 2008 & 2009 & 2010 & 2011 & 2012 \\
\hline $\begin{array}{l}\text { Bosnia and } \\
\text { Herzegovina }\end{array}$ & 5.5 & 5.74 & 6.65 & 8.37 & 10.02 & 10.94 & 12.4 & 15.28 & 18.54 & 17.08 & 16.77 & 18.25 & 16.85 \\
\hline Macedonia & 3.58 & 3.43 & 3.79 & 4.75 & 5.51 & 5.98 & 6.56 & 8.15 & 9.83 & 9.31 & 9.33 & 10.39 & 9.57 \\
\hline Mont & 0.98 & 1.15 & 1.28 & 1.7 & 2.07 & 2.25 & 2.69 & 3.67 & 4.53 & 4.15 & 4.11 & 4.5 & 4.04 \\
\hline $\begin{array}{l}\text { Bosnia and } \\
\text { Herzegovina }\end{array}$ & 28.69 & 28.39 & 24.34 & 30.28 & 32.24 & 32.14 & 36.65 & 43.33 & 41.06 & 31.66 & 35.5 & 31.3 & 31.16 \\
\hline Macedonia & 48.63 & 42.69 & 38.02 & 38.06 & 39.93 & 44.13 & 46.62 & 52.36 & 50.89 & 39.18 & 46.56 & 54.85 & 53.6 \\
\hline Montenegro & 36.81 & 38.42 & 35.36 & 30.61 & 42.02 & 46.8 & 48.45 & 43.71 & 38.83 & 32.07 & 34.71 & 42.75 & 44.12 \\
\hline & & & & & & & & & & & & & \\
\hline $\begin{array}{l}\text { Bosnia and } \\
\text { Herzegovina }\end{array}$ & 0.15 & 0.12 & 0.27 & 0.38 & 0.71 & 0.62 & 0.85 & 1.8 & 1.0 & 0.14 & 0.44 & 0.47 & 0.35 \\
\hline Macedonia & 0.22 & 0.45 & 0.11 & 0.12 & 0.32 & 0.15 & 0.43 & 0.73 & 0.61 & 0.26 & 0.3 & 0.5 & 0.28 \\
\hline Mont & & & - & & & & 0 & 0.94 & 0.96 & 1.55 & 0.76 & 0.56 & 0.62 \\
\hline & & & & & & & & & & & & & \\
\hline $\begin{array}{l}\text { Bosnia and } \\
\text { Herzegovina }\end{array}$ & 75.51 & 75.92 & 70.92 & 83.16 & 77.49 & 71.68 & 65.96 & 79.87 & 77.75 & 54.39 & 56.08 & 55.26 & 55.14 \\
\hline & & & & & & & & & 76.19 & 1.03 & 65.26 & 74.47 & 76.26 \\
\hline Montenegro & 51.11 & 61.98 & 59.88 & 46.98 & 58.08 & 64.32 & 78.17 & 86.02 & 93.35 & 65.37 & 63.11 & 64.92 & 68.79 \\
\hline
\end{tabular}

Note: Data for FDI and GDP are in bill.USD; data for exports and imports are given as a percentage of GDP; FDI are given as a net inflow

Source: World Bank, electronic database World Development Indicators, http://data.worldbank.org/data- catalog/worlddevelopment-indicators 


\section{References}

[1] C. Rodriguez, R. Bustillo, Foreign direct investment and the business cycle: new insights after the great recession, Prague Economic Papers. 24(2) (2015) 136-153.

[2] G. Wamser, Foreign (in)direct investment and corporate taxation, Canadian Journal of Economics/Revue canadienne d'Economique. 44(4) (2011)1497-1524.

[3] J. Forssbæck, L. Oxelheim, Corporate financial determinants of foreign direct investment, The Quarterly Review of Economics and Finance. 51 (2011) 269-282.

[4] H. Nishiyama, M. Yamaguchi, Foreign direct investment, international trade, and firm heterogeneity, Economic Modelling. 27 (2010) 184-195.

[5] D. Marjanović, P. Radojević, Foreign direct investments as an engine of economic growth and development of Serbia, in: H. Hanić et al. (Eds.), Post Crisis Recovery, BBA, IES, Belgrade, Serbia, 2013, pp. 349-364.

[6] O. Morrissey, M. Udomkerdmongkol, Governance, private investment and foreign direct investment in developing countries, World Development. 40(3) (2012) 437-445.

[7] U. Nwaogu, M. Ryan, FDI, Foreign aid, remittance and economic growth in developing countries, Review of Development Economics. 19(1) (2015) 100-115.

[8] G. De Simone, M. Manchin, Outward migration and inward FDI: factor mobility between Eastern and Western Europe, Review of International Economics. 20(3) (2012) 600-615.

[9] P. Hlavacek, B. Bal-Domanska, Impact of foreign direct investment on economic growth in Central and Eastern European countries, Engineering Economics. 27(3) (2016) 294-303.

[10] C. Russu, Foreign direct investment in the European Union, Economic Insights-Trends and Challenges. V(1) (2016) 51-63.

[11] V. Castro, The impact of the European Union fiscal rules on economic growth, Journal of Macroeconomics. 33 (2011) 313-326.

[12] OECD, Attracting Foreign Direct Investment for Development, Paris, 2002.

[13] M. Alguacil, A. Cuadros, V. Orts, Inward FDI and growth: the role of macroeconomic and institutional environment, Journal of Policy Modeling. 33 (2011) 481-496.

[14] D.G. Neto, F.J. Veiga, Financial globalization, convergence and growth: The role of foreign direct investment, Journal of International Money and Finance. 37 (2013) 161-186.

[15] A. Zdravković I. Domazet, V. Nikitović, Uticaj demografskog starenja na održivost javnih finansija u Srbiji, Stanovništvo. 50(1) (2012) 19-44. (in Serbian)

[16] E. Demirhan, M. Masca, Determinants of foreign direct investment flows to developing countries: a cross-sectional analysis, Prague Economic Papers. 17(4) (2008) 356-369.

[17] I. Domazet, D. Filimonović, O. Pantić, Trgovina i pristup EU - primer Srbije, Ekonomika preduzeća. 62(3-4) (2014) 217-227. (in Serbian)

[18] D.T. Wang et al., When does FDI matter? The roles of local institutions and ethnic origins of FDI, International Business Review. 22 (2013) 450-465.

[19] J. Gorbunova, D. Infante, J. Smirnova, New evidence od FDI determinants: an appraisal over the transition period, Prague Economic Papers. 21(2) (2012) 129-149.

[20] D. Dharmapala, N. Riedel, Earnings shocks and tax-motivated income-shifting: evidence from European multinationals, Journal of Public Economics. 97 (2013) 95-107.

[21] B.G. Buchanan, Q.V. Le, M. Rishi, Foreign direct investment and institutional quality: some empirical evidence, International Review of Financial Analysis. 21 (2012) 81-89. 
[22] A. Dis Oladottir et al., Strategic complexity and global expansion: an empirical study of newcomer Multinational Corporations from small economies, Journal of World Business. 47 (2012) 686-695.

[23] UNCTAD, World investment report, New York and Geneva, 2010-2013.

[24] S.S. Makki Somwaru, Impact of Foreign Direct Investment and trade on economic growth: evidence from developing countries, American Journal of Agricultural Economics. 86 (2004) 795-801.

[25] M. Mahmoodi, E. Mahmoodi, Foreign direct investment, exports and economic growth: evidence from two panels of developing countries, Economic Research - Ekonomska istrazivanja. 29(1) (2016) 938-949.

[26] X.B. Liu, Relationships between economic growth, foreign direct investment and trade: evidence from China, Applied Economics. 34(1) (2002) 1433-1440.

[27] H.K. Nath, Trade, foreign direct investment and growth: Evidence from transition economies, Comparative Economic Studies. 51 (2009) 20-50.

[28] B. Ćorić, G. Pugh, Foreign direct investment and output growth volatility: a worldwide analysis, International Review of Economics and Finance. 25 (2013) 260-271.

[29] UNCTAD, Towards a new generation of invetment policies, New York and Geneva, 2012.

[30] M. Mehrara et al., Dynamic causal relationships among GDP, exports, and Foreign Direct Investment (FDI) in the developing countries, International Letters of Social and Humanistic Sciences. 14 (2014) 1-19.

[31] M. Mehrara, F. Ghamati, Financial development and economic growth in developed countries, International Letters of Social and Humanistic Sciences. 36 (2014) 75-81.

[32] V. Botrić, Foreign direct investment in the western Balkans: Privatization, institutional change, and banking sector dominance, Economic Annals. 55 (187) 7-30.

[33] S. Estrin, M. Uvalic, Foreign Direct Investment in the Western Balkans: what role has it playes during transition, Comparative Economic Studies. 58(3) (2016) 455-483.

[34] J. Deichmann, Historical legacies and Foreign Direct Investment in Bosna and Herzegovina, South East European Journal of Economics and Business. 7(1) (2012) 7-18.

[35] D. Jacimovic, M Jocovic, Foreign Investment and Trade in the Western Balkan - focus on economic and legal system, Journal of Advanced Management Science. 2(4) (2014) 301-305.

[36] Z. Murgasova et al., The Western Balkans: 15 years of economic transition, IMF, Washington, 2015.

[37] G.H. Popescu, FDI and economic growth in Central and Eastern Europe, Sustainability. 6(11) (2014) 8149-8163.

[38] L.P. Dana, When economies change hands: a survey of entrepreneurship in the emerging markets of Europe from the Balkans to the Baltic states, Routledge, New York \& London, 2010.

[39] J. Žugić, Foreign Direct Investment and Global Economic Crisis in the Western Balkans, Journal on European Perspectives of the Western Balkans. 3(1) (2011) 69-90.

[40] N. Baltaci, M. Sahin, Relationship between Tax Regulations and Direct Foreign Capital: case of Balkan countries, Turkish Economic Review. 3(4) (2016) 642-651.

[41] C. Chen, Information, incentives and multinational firms, Journal of International Economics. 85 (2011) 147-158. 
[42] Z. Vukanović, Foreign Direct Investment inflows into the South East European media market: towards a hybrid business model, Springer, 2016.

[43] A. Bitzenis, The Balkans: Foreign Direct Investment and EU accession, Ashgate, 2013.

[44] I. Kersan-Škabić, The importance of Corporate Taxation for FDI attractiveness of Southeast European countries, Paneconomicus. 62(1) (2015) 105-122.

[45] T. Balliu, A. GaceLlozana, Commonalities and differences of tax system in West Balkan countries. Comparative analysis, European Journal of Social Sciences, Education and Research. 3(1) (2015) 157-164.

[46] J. Becker et al., Corporate tax effects on the quality and quantity of FDI, European Economic Review. 56(8) (2012) 1495-1511.

[47] H. Šimović, M. Mihelja Žaja, Tax incentives in Western Balkan vountries, International Journal of Social, Behavioral, Educational, Economic, Business and Industrial Engineering. 4(6) (2010) 731-736.

[48] M. Yuce, R.A.F. Mercimek, Investments and investment incentives in the Balkan states, Annals of the "Constantin Brancusi" University of Targu Jiu. 2 (2016) 53-64.

[49] S. Leiser, The diffusion of state tax incentives for business, Public Finance Review. 45(3) (2015) 334-363. 